\title{
High levels of reactive gaseous mercury observed at a high elevation research laboratory in the Rocky Mountains
}

\author{
X. Faïn ${ }^{1}$, D. Obrist ${ }^{1}$, A. G. Hallar ${ }^{1,2}$, I. Mccubbin ${ }^{1,2}$, and T. Rahn ${ }^{3}$ \\ ${ }^{1}$ Division of Atmospheric Sciences, Desert Research Institute, 2215 Raggio Parkway, Reno, NV, USA \\ ${ }^{2}$ Storm Peak Laboratory, Desert Research Institute, P.O. Box 882530 Steamboat Springs, CO, USA \\ ${ }^{3}$ Earth and Environmental Sciences Division, Los Alamos National Laboratory, P.O. Box 1663 Los Alamos, NM, USA
}

Received: 15 April 2009 - Published in Atmos. Chem. Phys. Discuss.: 24 July 2009

Revised: 22 September 2009 - Accepted: 7 October 2009 - Published: 23 October 2009

\begin{abstract}
The chemical cycling and spatiotemporal distribution of mercury in the troposphere is poorly understood. We measured gaseous elemental mercury (GEM), reactive gaseous mercury (RGM) and particulate mercury $\left(\mathrm{Hg}_{P}\right)$ along with carbon monoxide $(\mathrm{CO})$, ozone $\left(\mathrm{O}_{3}\right)$, aerosols, and meteorological variables at Storm Peak Laboratory at an elevation of $3200 \mathrm{~m}$ a.s.l., in Colorado, from 28 April to 1 July 2008. The mean mercury concentrations were $1.6 \mathrm{ng} \mathrm{m}^{-3}$ (GEM), $20 \mathrm{pg} \mathrm{m}^{-3}$ (RGM) and $9 \mathrm{pg} \mathrm{m}^{-3}$ $\left(\mathrm{Hg}_{P}\right)$. We observed eight events of strongly enhanced atmospheric RGM levels with maximum concentrations up to $137 \mathrm{pg} \mathrm{m}^{-3}$. RGM enhancement events lasted for long time periods of 2 to 6 days showing both enriched level during daytime and nighttime when other tracers (e.g., aerosols) showed different representations of boundary layer air and free tropospheric air. During seven of these events, RGM was inversely correlated to GEM (RGM/GEM regression slope $\sim-0.1$ ), but did not exhibit correlations with ozone, carbon monoxide, or aerosol concentrations. Relative humidity was the dominant factor affecting RGM levels with high RGM levels always present whenever relative humidity was below 40 to $50 \%$. We conclude that RGM enhancements observed at Storm Peak Laboratory were not induced by pollution events and were related to oxidation of tropospheric GEM. High RGM levels were not limited to upper tropospheric or stratospherically influenced air masses, indicating that entrainment processes and deep vertical mixing of free tropospheric air enriched in RGM may lead to high RGM levels throughout the troposphere and into the boundary layer over the Western United States. Based on backtrajectory analysis and a lack of mass balance between RGM and GEM, atmospheric production of RGM may also have occurred in some distance allowing for scavenging and/or deposition of RGM
\end{abstract}

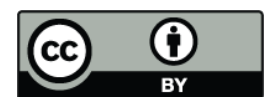

Correspondence to: X. Faïn (xavier.fain@dri.edu) prior to reaching the laboratory. Our observations provide evidence that the tropospheric pool of mercury is frequently enriched in divalent mercury, that high RGM levels are not limited to upper tropospheric air masses, but that the buildup of high RGM in the troposphere is limited to the presence of dry air.

\section{Introduction}

Mercury is a worldwide pollutant globally dispersed in the environment by large-scale atmospheric circulation. Various natural and anthropogenic sources emit mercury to the atmosphere, either as gaseous elemental mercury (GEM; $\mathrm{Hg}^{0}$ ) or as divalent mercury species. Divalent mercury species are typically measured in two forms: reactive gaseous mercury (RGM), defined operationally as any gaseous mercury compounds that adsorb onto $\mathrm{KCl}$ (potassium chloride) denuders, and particulate-bound mercury $\left(\mathrm{Hg}_{P}\right)$ which are trapped by quartz-fiber filters. RGM is water-soluble, and can be rapidly deposited to surfaces or sequestered by rain or cloud drops (Schroeder and Munthe, 1998). $\mathrm{Hg}_{P}$ is limited to the lifetime of particles which is typically less than 10 days (Schroeder and Munthe, 1998). Contrarily, GEM has low solubility in water and estimates of its longer lifetime range from 0.5 to 2 years (Schroeder and Munthe, 1998; Bergan and Rodhe, 2001; Selin and Jacob, 2008), although GEM lifetime is still not well understood. Hence, the speciation of atmospheric mercury and, specifically, the abundance of reactive mercury forms with high deposition velocities, are of utmost importance for regional and local deposition loads and for the understanding of global chemical cycling of mercury in the atmosphere.

Many atmospheric observations have been conducted in the lower troposphere where GEM generally represents over $95 \%$ of the total mercury, with concentrations varying over a range of $\sim 1-5 \mathrm{ng} \mathrm{m}^{-3}$ (Valente et al., 2007), and RGM

Published by Copernicus Publications on behalf of the European Geosciences Union. 
and $\mathrm{Hg}_{P}$ in the range of few percent of the total mercury (Schroeder and Munthe, 1998). The vast majority of measurements of atmospheric mercury species have been conducted at ground-level, and these low altitude data suggest that little RGM and $\mathrm{Hg}_{P}$ is present distant from sources. Recent aircraft campaigns over the Pacific, however, indicated a strong depletion of GEM in the upper troposphere and lower stratosphere, which is hypothesized to be due to efficient oxidation and transformation of GEM to RGM and $\mathrm{Hg}_{p}$ (Friedli et al., 2004; Radke et al., 2007; Talbot et al., 2007; Slemr et al., 2009). Interestingly, global chemical model showed that divalent mercury species could dominate GEM in the upper troposphere and stratosphere, and that subsidence could be a significant source of divalent mercury to remote surface sites (Geos-CHEM model: Selin and Jacob, 2008; CMAQ model: Sillman et al., 2007). Direct measurements of RGM and $\mathrm{Hg}_{P}$ onboard of aircraft are presently not available, due to the long collection period required ( $2-3 \mathrm{~h}$ using the 1130 and 1135 Tekran units, see Materials and Methods). In situ measurements of aerosols collected in the lower stratosphere and analyzed using mass spectrometry indicate, however, significant enrichment of $\operatorname{Hg}_{P}$ (Murphy et al., 2006).

Decreases of GEM and enhanced levels of RGM were observed frequently at night at a high elevation research station (2700 m a.s.1.), Mt. Bachelor observatory in Oregon, USA, when the air was considered representative of the free troposphere (Swartzendruber et al., 2006). The authors suggested direct oxidation of GEM by ozone, $\mathrm{OH}$, or possibly other oxidants in the free troposphere as sources of RGM, which then could reach the laboratory during nighttime downflow processes (i.e., katabatic winds) induced by the mountain slopes. Gas-phase reactions with ozone and $\mathrm{OH}$ were the first oxidation mechanisms for atmospheric GEM identified in the troposphere. Model simulations, however, have shown that the determined reaction rate of GEM with ozone alone cannot explain GEM temporal and spatial variations or the observed diurnal cycles of oxidized mercury (e.g., Hedgecock et al., 2005). Oxidation by $\mathrm{OH}$ radicals may lead to a lifetime of 115 days for GEM (Sommar et al., 2001; Pal and Ariya, 2004), but theoretical considerations indicate that oxidation of GEM by $\mathrm{OH}$ could be slower (Calvert and Lindberg, 2005) and $\mathrm{OH}$ oxidation may be insignificant under atmospheric conditions (Goodsite and Plane, 2004; Calvert and Lindberg, 2005). Bromine chemistry may play a major role in the atmospheric oxidation of GEM to reactive mercury species. GEM reacts with both $\mathrm{Cl}$ and $\mathrm{Br}$ radicals, and kinetics have been reported of comparable magnitude (Donohoue et al., 2005; Donohoue et al., 2006) or faster with chlorine atoms (Ariya et al., 2002), although, concentrations of $\mathrm{Cl}$ radicals are much lower than concentrations of $\mathrm{Br}$ radicals (Calvert and Lindberg, 2003). Raofie and Ariya (2004) also reported a gas-phase reaction of $\mathrm{BrO}$ with GEM, but could not exclude the possibility of heterogeneous mechanisms in their experimental set up. However, the homogeneous oxidation of GEM by BrO radicals is considered endothermic
(Shepler and Peterson, 2003; Tossel, 2003), and hence probably without importance in the atmosphere.

A lack of reactive mercury observations in the upper troposphere and the first observational and modeling results emphasize the need for increased measurements of reactive mercury in this region. Such data would improve our understanding of temporal and spatial distribution of all forms of mercury and of atmospheric mercury chemistry, and thus help to reduce uncertainties in model simulations. We report data of speciated atmospheric mercury levels at a high-altitude research station, Storm Peak Laboratory ( $3220 \mathrm{~m}$ a.s.l.) in the Rocky Mountains in Colorado, from April 28 to July 1, 2008 to study the presence and transformation of reactive mercury in the troposphere over the remote Western United States.

\section{Material and methods}

\subsection{Site description}

Storm Peak Laboratory is a high-elevation (3220 m a.s.1.) mountaintop research facility in the Park Range in Colorado on top of Steamboat Springs ski resort almost $1500 \mathrm{~km}$ from the US west coast. The laboratory marks the location of the Continental Divide and is situated on a $70 \mathrm{~km}$ northsouth mountain range perpendicular to the prevailing westerly winds, thus providing a clear upwind fetch. The Park Range receives some of the largest precipitation totals in Colorado with most precipitation falling as snow and typical annual snowfalls at the laboratory in the range of $400-900 \mathrm{~cm}$ (Borys and Wetzel, 1997). The laboratory's mountaintop location produces frequent transitions from free tropospheric air to boundary layer and thus allows for time-extended measurements of free tropospheric, in-cloud, and boundary layer air (e.g. Borys and Wetzel, 1997). The site has been used in cloud and aerosol studies for more than 20 years and a considerable depth of knowledge has been acquired on aerosol patterns and interaction of aerosols with clouds (Hindman et al., 1994; Borys and Wetzel, 1997; Lowenthal et al., 2002, 2004).

\subsection{Mercury measurements}

Atmospheric concentrations of gaseous elemental mercury, reactive gaseous mercury and particulate mercury (GEM, RGM and $\mathrm{Hg}_{P}$ ) were measured from 28 April to 1 July 2008. GEM was determined using a Tekran 2537A vaporphase mercury analyzer. The 2537A instrument collect the air stream on two gold cartridges. GEM is thermally desorbed and detected by cold vapor atomic fluorescence spectrometry at $253.7 \mathrm{~nm}$. Use of dual gold cartridges allowed alternate sampling and desorption, resulting in continuous measurement of GEM on a predefined time base. A precision mass flow meter supplies the $2537 \mathrm{~A}$ with a sample volume referenced to STP (Standard Temperature and Pressure: $0^{\circ} \mathrm{C}$, $1 \mathrm{~atm})$. Set-up, accuracy, and precision of this instrument 
have been evaluated previously during field comparisons at an urban/industrial site (Ebinghaus et al., 1999) and a remote marine background location (Schroeder et al., 1995).

Atmospheric mercury speciation was determined by integrating Tekran 1130 and 1135 speciation units, as front-end units to the Tekran 2537A. Both units were positioned on the roof of the Storm Peak Laboratory, at $2 \mathrm{~m}$ high, and attached to the pump module and 2537A analyzer by a heated $\left(50^{\circ} \mathrm{C}\right)$ umbilical line $(10 \mathrm{~m}$ long). The Tekran 1130 and 1135 units were configured to collect 1-hour RGM and $\mathrm{Hg}_{P}$ samples. During the 1-h sampling period, 5-min GEM samples were continuously quantified by the 2537A analyzer. Ambient air is pumped through a denuder, a quartz filter $(0.1 \mu \mathrm{m})$ and a pyrolyzer. Specifically, a potassium chloride coated quartz annular denuder is housed in the Tekran 1130 unit where RGM is collected (the most probable candidate compounds are $\mathrm{HgCl}_{2}$ and $\mathrm{HgBr}_{2}$ ). The Tekran 1135 unit consists of a quartz regenerable particulate filter housed in a glass pyrolyzer where $\mathrm{Hg}_{p}$ is collected after passing through a $2.5 \mu \mathrm{m}$ cutoff impactor (Landis et al., 2002). We set the Tekran 2537A sample flow to $0.81 \mathrm{~min}^{-1}$ (highest flow value allowed by the internal pump due to the high elevation) and the Tekran 1130 pump flow to $6.01 \mathrm{~min}^{-1}$, thus allowing a total flow of $6.81 \mathrm{~min}^{-1}$ during the 1-h time period. However, these flow values set on both instruments corresponds to STP conditions. Considering the mean pressure and temperature at Storm Peak Laboratory during our sampling period $\left(5^{\circ} \mathrm{C}\right.$, $698 \mathrm{mbar}$ ), we actually sampled a total flow of $10.01 \mathrm{~min}^{-1}$, which allowed a $2.5 \mu \mathrm{m}$ particle size cutoff by the impactor.

Following 1-h sampling periods, the instruments switch to analysis mode. The system is first flushed with mercury free air to clean out the lines of residual ambient air. The particulate filter is heated to $800^{\circ} \mathrm{C}$ for $\mathrm{Hg}_{P}$ desorption and quantification as GEM by the Tekran 2537A, followed by heating of the denuder at $500^{\circ} \mathrm{C}$ for thermal desorption of the collected RGM and quantified as GEM by the analyzer. To ensure clean operation, the denuders, denuder module glassware, impactor frits, regenerable particulate filters, and soda lime traps (to prevent gold cartridge passivation) were replaced and cleaned on a $2-3$ weeks basis. To avoid that high humidity corrode of the zero air canisters, the airstream leading into the 1130 pump module during blanks measurement was pumped through a 1102 air dryer Tekran unit.

The Model 2537A was recalibrated every 26-h using its internal permeation source. Blanks for the 2537A were measured during each internal calibration cycle and were consistently $0.00 \mathrm{ng} \mathrm{m}^{-3}$. The manufacturer's reported detection limit for 5 min samples measured with the $2537 \mathrm{~A}$ of $0.10 \mathrm{ng} \mathrm{m}^{-3}$ (http://www.tekran.com/). Detection limit for the 2537A Tekran analyzer was reported by Aspmo et al. (2005) as $0.17 \mathrm{ng} \mathrm{m}^{-3}$. Currently no calibration procedures are available for the 1130 and 1135 speciation units. During our study, the detection limit for RGM and $\mathrm{Hg}_{P}$, calculated as 3 times the standard deviation of the 1130/1135 system blank, was $2 \mathrm{pg} \mathrm{m}^{-3}$.

\subsection{Meteorological and chemical measurements}

Meteorological instruments used in this study were research grade temperature, pressure, wind speed and direction, and relative humidity sensors (Campbell Scientific, Inc., Met One and Vaisala interfaced to data loggers). Atmospheric tracers included ozone concentrations, aerosol concentrations, and carbon monoxide (CO) concentrations. Aerosol and CO analyzers, however, were not operational continuously, and data were available only $34 \%$ and $46 \%$ of the measurement period, respectively. Ozone was measured with a Dasibi Ozone Monitor (Dasibi Environmental Corp., Glendale, CA). The instrument has a measurement range of 0.001-1.000 ppm, an automatic zero, and span test. The instrument is calibrated every six months and the UV lamp is replaced if any degradation in signal is observed. Aerosol number concentrations were measured using a stand-alone TSI model 3010 Concentration Particle Counter (CPC) for particles with diameters larger than $10 \mathrm{~nm}$. The TSI CPC instrument is annually sent back to the manufacturer for maintenance and calibrations using National Institute of Standards and Technology (NIST) standards. In addition, the instruments are routinely checked at Storm Peak Laboratory for accurate flow rates. Carbon monoxide concentrations were measured using an isothermal gas chromatograph (Peak Laboratories Model 1 RCP, Mountain View, CA) configured with a reduction gas detector. Its high sensitivity (as low as $10 \mathrm{ppb}$ ) and negligible matrix effects from other permanent gases assure reliable detection of ambient and enhanced $\mathrm{CO}$ concentrations. The instrument is self-calibrated approximately every $30 \mathrm{~min}$ with known standards of carbon monoxide (54 and $153 \mathrm{ppbv}$ ). Meteorological data and aerosol concentration data are uploaded to the Western Regional Climate Center (http://www.wrcc.dri.edu/) database every $5 \mathrm{~min}$. All data were averaged to 2 -h mean values which were used for all further analyses.

\subsection{Calculations of air mass trajectories}

NOAA Hybrid Single-Particle Lagrangian integrated trajectories (HYSPLIT) (Draxler and Rolph, 2003; Rolph, 2003) were calculated for specific dates to determine the origin of air masses measured at Storm Peak Laboratory. In this study, 10-day back-trajectories were calculated in ensemble forms which calculate 27 trajectories from a selected starting point. Each member of the trajectory ensemble is calculated by offsetting meteorological data by one meteorological grid point (1 degree) in the horizontal (both latitudinal and longitudinal) and 0.01 sigma units $(250 \mathrm{~m})$ in the vertical for the selected starting point. HYSPLIT was run with the National Centers for Environmental Prediction's (NCEP) Global Data Assimilation System (GDAS) data set. More information on this data set can be found at http://www.emc.ncep.noaa.gov/gmb/ gdas/. The computational altitude was selected based on the altitude which most closely represents the common pressure at the lab, $675 \mathrm{mb}$. The altitude selected for this data set was 
Table 1. Summary of the mercury data collected at Storm Peak Laboratory from 28 April to 1 July 2008, including characterization of 8 specific RGM enhancement events. Table includes Pearson's correlation coefficients $r$ between RGM and GEM, RGM and PM, as well as RGM and water vapor mixing ratio for each individual event. Also given are RGM/GEM regression slopes for each of these events.

\begin{tabular}{|c|c|c|c|c|c|c|c|c|c|c|}
\hline & & All days & Event \#1 & Event \#2 & Event \#3 & Event \#4 & Event \#5 & Event \#6 & Event \#7 & Event \#8 \\
\hline & & 4/28/08, 07:00 p.m. & 4/28/08, 07:00 p.m. & 5/2/08, 11:00, p.m. & 5/10/08, 01:00 p.m. & 5/16/08, 07:00 p.m. & 5/28/08, 05:00, p.m. & 6/9/08, 07:00 a.m. & 6/13/08, 07:00 a.m. & 6/25/08, 05:00 a.m. \\
\hline $\begin{array}{l}\text { Ending date and time } \\
\text { Duration (hours) }\end{array}$ & & 7/01/08, 11:00 a.m. & $\begin{array}{c}\text { 5/1/08, 03:00 a.m. } \\
56\end{array}$ & $\begin{array}{c}\text { 5/7/08, } 11: 00 \text { p.m. } \\
118\end{array}$ & $\begin{array}{c}5 / 12 / 08,07: 00 \text { p.m. } \\
54\end{array}$ & $\begin{array}{c}\text { 5/21/08, 09:00 p.m. } \\
134\end{array}$ & $\begin{array}{c}6 / 3 / 08,11: 00 \mathrm{pm} \\
150\end{array}$ & $\begin{array}{c}6 / 10 / 08,11: 00 \text { p.m. } \\
40\end{array}$ & $\begin{array}{c}\text { 6/17/08, 09:00 p.m. } \\
118\end{array}$ & $\begin{array}{c}\text { 6/28/08, 07:00 p.m. } \\
86\end{array}$ \\
\hline$n^{\mathrm{a}}$ & & 760 & 24 & 59 & 27 & 66 & 74 & 21 & 59 & 43 \\
\hline Gaseous & Mean \pm StdDev & $1.6 \pm 0.3$ & $1.5 \pm 0.2$ & $1.5 \pm 0.1$ & $1.5 \pm 0.1$ & $1.5 \pm 0.2$ & $1.5 \pm 0.2$ & $1.5 \pm 0.2$ & $1.6 \pm 0.5$ & $1.5 \pm 0.1$ \\
\hline Elemental & Min & 1.2 & 1.3 & 1.3 & 1.4 & 1.3 & 1.2 & 1.2 & 1.2 & 1.3 \\
\hline Mercury (GEM) $\mathrm{ng} \mathrm{m}^{-3}$ & Max & 5.0 & 1.9 & 1.9 & 1.7 & 2.1 & 2.0 & 1.9 & 5.0 & 1.9 \\
\hline Reactive & Mean \pm StdDev & $20 \pm 21$ & $67 \pm 23$ & $21 \pm 13$ & $21 \pm 17$ & $28 \pm 27$ & $32 \pm 24$ & $36 \pm 25$ & $40 \pm 21$ & $30 \pm 15$ \\
\hline Gaseous & Min & 0 & 7 & 1 & 1 & 0 & 1 & 2 & 2 & 5 \\
\hline $\begin{array}{l}\text { Mercury } \\
\left(\text { RGM) }{ }^{-3} \text { m }^{-3}\right.\end{array}$ & & & & & & & & & & \\
\hline (RGM) $\mathrm{pg} \mathrm{m}^{-3}$ & Max & 137 & 95 & 58 & 52 & 137 & 84 & 93 & 125 & 71 \\
\hline \multirow{3}{*}{$\begin{array}{l}\text { Particulate Mercury } \\
\left(\mathrm{Hg}_{P}\right) \mathrm{pg} \mathrm{m}^{-3}\end{array}$} & Mean \pm StdDev & $9 \pm 6$ & $13 \pm 6$ & $10 \pm 3$ & $6 \pm 6$ & $9 \pm 4$ & $6 \pm 4$ & $6 \pm 3$ & $16 \pm 9$ & $13 \pm 5$ \\
\hline & Min & 0 & 3 & 3 & 1 & 2 & 0 & 3 & 4 & 4 \\
\hline & $\operatorname{Max}$ & 33 & 32 & 20 & 10 & 22 & 15 & 11 & 31 & 28 \\
\hline $\begin{array}{l}\text { RGM/GEM } \\
\text { regression slope }\end{array}$ & & & -0.09 & -0.08 & -0.18 & -0.10 & -0.09 & -0.09 & -0.01 & -0.07 \\
\hline$r_{\mathrm{RGM}-\mathrm{GEM}} \mathrm{b}^{\mathrm{r}}$ & & & -0.71 & -0.79 & -0.86 & -0.62 & -0.76 & -0.62 & 0.10 & -0.62 \\
\hline$r_{\mathrm{RGM}}-\mathrm{PM}^{\mathrm{b}}$ & & & -0.26 & 0.44 & 0.30 & -0.28 & -0.62 & -0.28 & -0.06 & 0.01 \\
\hline$r_{\text {RGM-WaterVapor }} \mathrm{b}, \mathrm{c}$ & & & - & -0.52 & -0.33 & -0.46 & -0.50 & -0.45 & -0.35 & -0.48 \\
\hline
\end{tabular}

a $n$ is the number of 2-h sampling periods for GEM, RGM and $\mathrm{Hg} P$

$\mathrm{b}$ Correlations significant at $p<0.01$ are indicated in bold

$\mathrm{c}$ Water vapor data were not available for event \#1

approximately $1.8 \mathrm{~km}$ above sea level which is based on the average altitude represented by the $1 \mathrm{~km}$ grid.

\section{Results and discussion}

\subsection{Spring patterns of atmospheric mercury species}

Atmospheric GEM, RGM and $\mathrm{Hg}_{P}$ were investigated at Storm Peak Laboratory during a 64 day period, from 28 April to 1 July 2008 . We experienced two short periods with instrument failures (from May 26 to 28, and from 18 to 21 June). GEM, RGM and $\mathrm{Hg}_{P}$ concentrations, thus collected during 59 days, were compiled into 1-h mean values which correspond to the speciation collection period. A complete time series of the three mercury species is plotted in Fig. 1. The mean GEM concentration and its respective standard deviation was $1.6 \pm 0.3 \mathrm{ng} \mathrm{m}^{-3}$. GEM minimum value was $1.2 \mathrm{ng} \mathrm{m}^{-3}$ and on eight days GEM levels exceeded $2.0 \mathrm{ng} \mathrm{m}^{-3}$. On two days (15 May and 18 June), GEM values exceeded $3 \mathrm{ng} \mathrm{m}^{-3}$ with a maximum value of $5.0 \mathrm{ng} \mathrm{m}^{-3}$ ). These specifically high pollution events are discussed elsewhere (Hallar et al., 2008). GEM concentrations observed at Storm Peak Laboratory during spring 2008 are within the range of values reported from 22 rural sites in the northern hemisphere (i.e. $1.7 \pm 0.3 \mathrm{ng} \mathrm{m}^{-3}$ ) (Valente et al., 2007), and close to an average level of $1.51 \pm 0.12 \mathrm{ng} \mathrm{m}^{-3}$ reported at the same location during spring 2007 by Obrist et al. (2008).

Mean concentrations and respective standard deviations for RGM and $\mathrm{Hg}_{P}$ were $20 \pm 21 \mathrm{pg} \mathrm{m}^{-3}$ and $9 \pm 6 \mathrm{pg} \mathrm{m}^{-3}$ for our entire measurement period. $\mathrm{RGM}$ and $\mathrm{Hg}_{P}$ measurements for rural sites in the western United States have been reported at Yellowstone National Park in summer 2003 (RGM range: <d.1. to $5 \mathrm{pg} \mathrm{m}^{-3} ; \mathrm{Hg}_{P}$ range: $<$ d.l. to
$30 \mathrm{pg} \mathrm{m}^{-3}$ ) (Hall et al., 2006), in southern New Mexico in 2001-2002 (RGM range: 2 to $25 \mathrm{pg} \mathrm{m}^{-3} ; \mathrm{Hg}_{P}$ range: 1 to $7 \mathrm{pg} \mathrm{m}^{-3}$ ) (Caldwell et al., 2006), and at two sites in northern Nevada (RGM: $13 \pm 18$ and $13 \pm 12 \mathrm{pg} \mathrm{m}^{-3}, \mathrm{Hg}_{P}: 9 \pm 7$ and $7 \pm 8 \mathrm{pg} \mathrm{m}^{-3}$ ) (Lyman and Gustin, 2008). While $\mathrm{Hg}_{P}$ concentrations at Storm Peak Laboratory were within ranges reported for these rural sites, RGM concentrations were considerably higher. Furthermore, RGM at Storm Peak Laboratory showed several multi-day enhancements periods with maximum level of 50 to $137 \mathrm{pg} \mathrm{m}^{-3}$. Specifically, we observed eight events of high RGM enhancements (marked in text and figures as RGM enhancement events \#1 to \#8). RGM enhancement events are defined as occurrences of RGM concentrations higher than the mean level reported for the entire study (i.e. $20 \mathrm{pg} \mathrm{m}^{-3}$, note that the high RGM levels measured on 22 June were not considered an enhancement event since instrument failure prevented a full characterization of this event).

During the eight RGM enhancement events, $\mathrm{Hg}_{P}$ levels were also slightly enhanced, with the exception of event \#5. However, significant positive correlation between $\mathrm{Hg}_{P}$ and RGM concentrations was only observed during event \#2 (Pearson coefficients $r$ of 0.4 , see Table 1). Except during event \#7, $\mathrm{Hg}_{P}$ levels were never correlated with aerosol or carbon monoxide. Means, maximums, minimums, and standard deviations of GEM, RGM, and $\mathrm{Hg}_{P}$ for the entire study and for each individual enhancement event are presented in Table 1.

At Storm Peak Laboratory, daytime surface heating can cause air masses enhanced with pollutants to rise from the valley floor, while nighttime air masses are often characterized by cleaner, drier tropospheric air masses as shown by previous studies (Lowenthal et al., 2002; Obrist et al., 2008). Diel pattern of water vapor mixing ratio was observed 

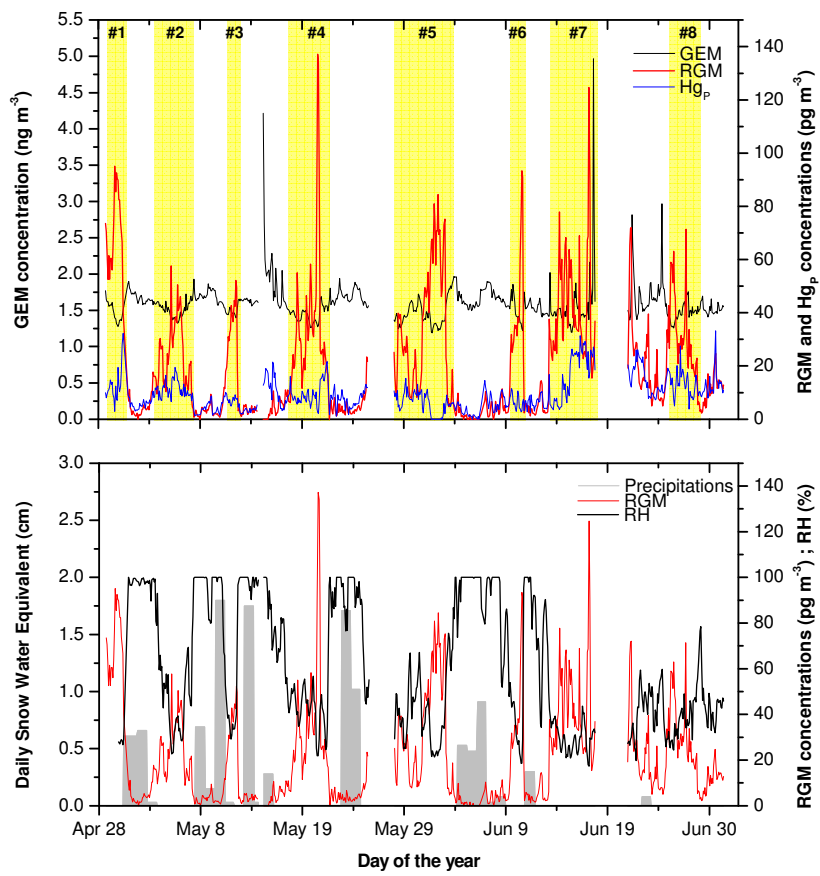

Fig. 1. Time series of GEM, RGM and $\mathrm{Hg}_{P}$ from April 28 to July 1 2008. Yellow areas highlight the 8 events with enhanced RGM levels (top panel). Records of precipitation (daily $\mathrm{cm}$ of snow water equivalent) and relative humidity (\%) for the study period are shown in the bottom panel.

during our study (Fig. 2), and such diel fluctuations of humidity and air pollutants due to local slope flows are typical of high-elevation research stations such as Jungfraujoch (Baltensperger et al., 1997), Sonnblick Mountain Observatory (Seibert et al., 1998), and Mt. Bachelor Observatory (Weiss-Penzias et al., 2006). At Storm Peak Laboratory, diel patterns of atmospheric GEM, however, were only pronounced in the fall and winter season, but not statistically significant in spring months in a previous study by Obrist and others (2008). Similarly, we did observe daytime increases in aerosols, water vapor mixing ratio, ozone (Fig. 2) in this study, but not statistically significant differences in GEM between nighttime and daytime concentrations from 28 April to 1 July 2008.

Consistent diurnal trends with RGM concentrations peaking between midday and early afternoon have been previously reported at different rural sites, and were attributed to physical boundary layer movement, ambient photochemistry, or air-surface exchange of mercury (Lindberg and Stratton, 1998; Gabriel et al., 2005; Poissant et al., 2005; Lyman and Gustin, 2008). At Storm Peak Laboratory, RGM also slightly peaked in the afternoon around 3:00 p.m. (Fig. 2). At Mt Bachelor (OR, USA) (Swartzendruber et al., 2006) and Mt Lulin (Taiwan) (Sheu et al., 2009), the only two others high altitude locations where atmospheric mercury speciation has been investigated to our knowledge, RGM peaks were observed at night. These patterns were linked to upslope (anabatic) winds during the day mixing in boundary layer air, and downslope (katabatic) wind which transported high-level, free tropospheric air masses enriched in RGM (see below) to the laboratories at night. Clearly, diel RGM patterns measured at Storm Peak Laboratory - notably much less pronounced compared to Mt Bachelor - showing nighttime minima differed from these previous observations. In addition, the occurrence of RGM enhancements always lasted for multi-day periods, up to a duration of six days, a starkly different pattern than at Mt. Bachelor where enhanced RGM levels were limited to relatively short nighttime spikes only. In the following sections, we are discussing possible reasons for the unique patterns observed at Storm Peak Laboratory.

\subsection{Are RGM enhancements related to anthropogenic pollution?}

No relationships between RGM and ozone, aerosols, or carbon monoxide concentrations were observed over the entire study (Fig. 3). Almost all individual RGM enhancement events did not show statistically significant correlations to any of these tracers either. The lack of correlations of RGM to these common combustion and pollution tracers indicates that high levels of RGM observed at Storm Peak Laboratory were not primarily due to anthropogenic pollution from local sources or due to pollution advected by long range transport processes. However, averaged diel patterns (Fig. 2) show slight daytime increases of RGM at the laboratory which mirrored by pronounced daytime increases of aerosols $(>300 \%$ of nighttime values) and minor enhancements of ozone, patterns that are attributed to surface heating processes and uplift of boundary layer air pollution as discussed above. A detailed look at a specific RGM enhancement event from 31 May to 3 June (event \#5, Fig. 4), however, shows that RGM enhancements were mainly unrelated to daytime/nighttime transitions of air masses. Carbon monoxide concentrations show peak concentrations in the afternoons of 1 and 3 June (peak levels up to $250 \mathrm{ppb}$ ) indicating presence of boundary layer sources at the laboratory, and coincided with enhancements of RGM. Maximum RGM levels during this event, however, occurred between 2 to 3 June during a time period when carbon monoxide and water vapor mixing ratio were low (as low as $130 \mathrm{ppb}$ and $2.8 \mathrm{~g} \mathrm{~kg}^{-1}$, respectively) representing air with more typical free tropospheric signatures (e.g., Swartzendruber et al., 2008). We conclude that RGM levels were not systematically related to pollution originating from the boundary layer during our study, although some contributions were likely due to presence of boundary layer air leading to a slight diurnal RGM enhancement along with other pollutant trace. If high RGM levels were systematically due to anthropogenic pollution, we should also have observed simultaneous increases in RGM and GEM, similar to such patterns reported from rural sites affected by close-by 

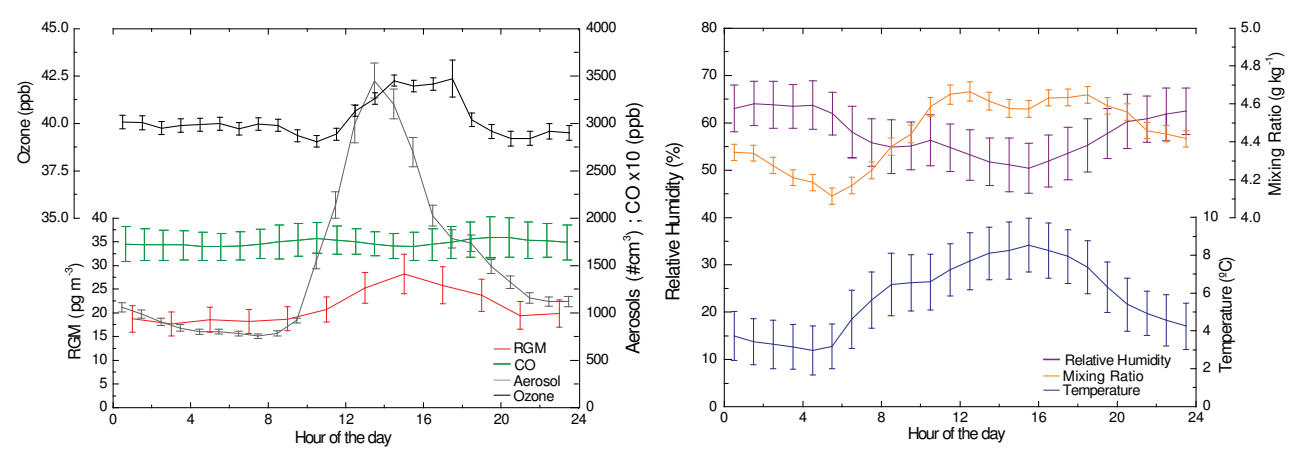

Fig. 2. 24-h, diel patterns of RGM, carbon monoxide, aerosol number concentration, ozone, relative humidity, Water vapor mixing ratio, and temperature averaged for the study period. Error bars represent standard errors. Times reported are local (i.e., Mountain Time: UTC-7).

urban pollution (e.g. Yatavelli et al., 2006). In contrast, we observed consistent inverse correlations between GEM and RGM throughout the study as discussed below.

\subsection{Tropospheric production and transport of RGM}

Our observations showed strong inverse relationships between GEM and RGM throughout the study (Figure 5; large panel represents all data from 28 April to 1 July). The inverse correlation becomes even more obvious when considering specifically data considered as RGM enhancement events (insert panel in Fig. 5, 54\% of data). Table 1 reports the Pearson coefficients $r$ and sloped between RGM and GEM for each of the eight individual events, with statistically significant linear inverse correlations between RGM and GEM for seven of the eight events (not significant for event \#7). The observed inverse correlations between RGM and GEM imply that high RGM levels observed at Storm Peak Laboratory were produced by atmospheric oxidation processes of GEM. Inverse correlations between RGM and GEM have been reported at Mt Bachelor and in polar regions and are attributed to a direct transformation of GEM to RGM and $\mathrm{Hg}_{p}$. At Mt Bachelor, a slope near unity (i.e., -0.89 ) between RGM and GEM was observed during nighttime RGM enhancements, indicating a near mass balance closure between RGM and GEM (Swartzendruber et al., 2006). During the well characterized polar Atmospheric Mercury Depletion Events, on average $40-50 \%$ of the converted RGM remains in the air while the remainder is deposited to the snow surface directly as RGM and/or scavenged by fine aerosols (Lindberg et al., 2002; Cobbett et al., 2007). In this study, the significant inverse correlations of GEM and RGM yielded slopes only between -0.07 and -0.18 , with an average slope of -0.10 . In other words, observed RGM levels only explained $\sim 10 \%$ of observed GEM depletion.

We attribute the obvious lack of mass closure between RGM and GEM in our study to deposition and scavenging of reactive mercury prior to reaching the research station. One possible reason includes significant surface deposition of reactive $\mathrm{Hg}$ species in close vicinity to the laboratory. Figure 6 reports 10-days HYSPLIT back-trajectories for the point of time of maximum RGM levels of each event. Interestingly, all back-trajectories indicate that air masses measured at Storm Peak Laboratory during RGM enhancements events showed source origins over the North Pacific Ocean. It is hence also possible that Storm Peak Laboratory experienced aged, far-traveled air masses, and that the location of the production of RGM occurred in quite some distance to Storm Peak Laboratory. One possible source area is over the Pacific Ocean, which would allow for considerable scavenging and deposition of RGM during air mass transport to Storm Peak Laboratory.

\subsection{Possible sources of observed high tropospheric RGM levels}

One possible mechanism for RGM production in the troposphere includes oxidation by halogens as discussed in detail in the introduction, but measurements in the free troposphere are just beginning to evolve. Ozone concentrations, however, were monitored but showed no correlations to RGM, neither throughout the entire study, nor specifically during any RGM enhancement event, nor during nighttime with higher representations of free tropospheric air masses (see discussion below). This is in contrast to results form Mt. Bachelor which showed positive correlation between RGM and ozone during nighttime periods $(p<0.01 ; r=0.68)$, and to strong inverse GEM/ozone correlations observed during research flights attributed to upper tropospheric/lower stratospheric influence (Talbot et al., 2007; Swartzendruber et al., 2008). Based on supporting GEOS-Chem modeling, Swartzendruber et al. (2006) concluded that the oxidation rate of $\mathrm{OH}$ and ozone was sufficient to reproduce the mean observed RGM levels, but not to reproduce the magnitude of nighttime RGM enhancements.

GEM oxidation involving ozone, $\mathrm{OH}$ and possibly $\mathrm{Br}$ radicals may lead to high RGM levels in the upper troposphere and lower stratosphere as evident by (i) GEM 

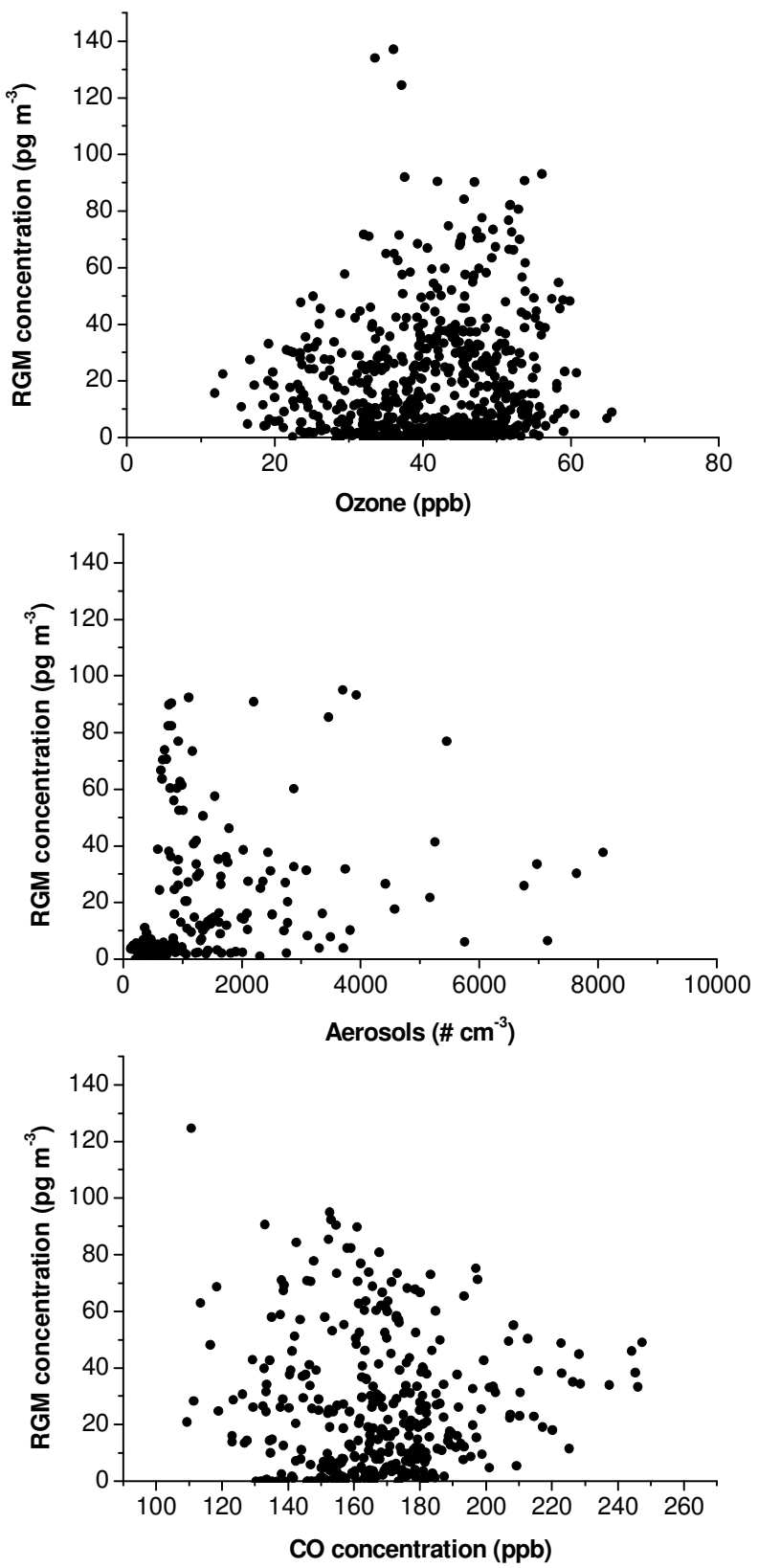

Fig. 3. RGM concentrations as a function of ozone, aerosols and carbon monoxide for the entire study period.

depletion above eight $\mathrm{km}$ altitude observed during research flights (e.g., Talbot et al., 2007) and by high levels of aerosolbound $\mathrm{Hg}_{P}$ in the lower stratosphere (Murphy et al., 2006). Most atmospheric chemistry models have been limited to gas-phase reaction of GEM with ozone and $\mathrm{OH}$ (e.g. Bergan and Rodhe, 2001; Dastoor and Larocque, 2004; Seigneur et al., 2006; Selin et al., 2007; Sillman et al., 2007), and these model simulations, e.g., using the CMAQ model, show that elevated RGM (>200 $\mathrm{pg} \mathrm{m}^{-3}$ ) can form intermittently over the Atlantic Ocean in air masses that have a cloudfree history (Sillman et al., 2007). Similar results were

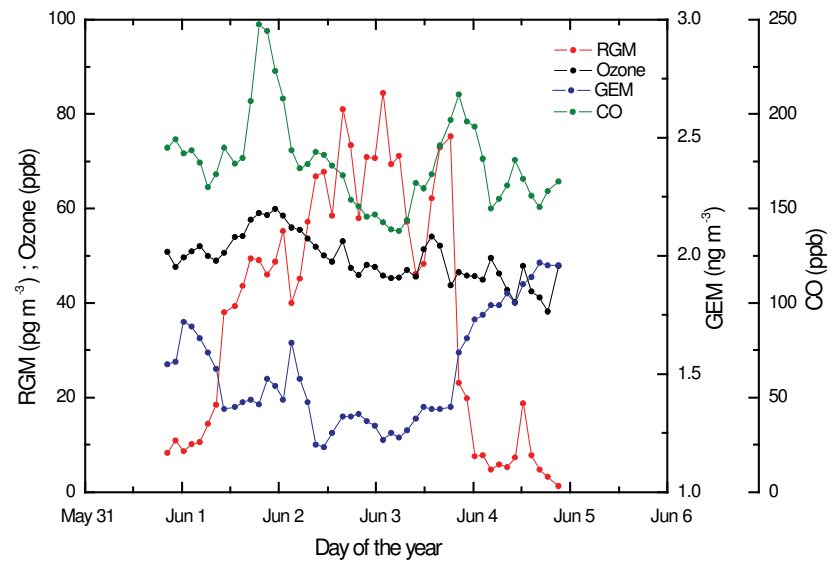

Fig. 4. Time series of GEM, RGM, ozone and carbon monoxide during the event \#5, from 31 May to 5 June 2008 (cf. Table 1 and Fig. 1).

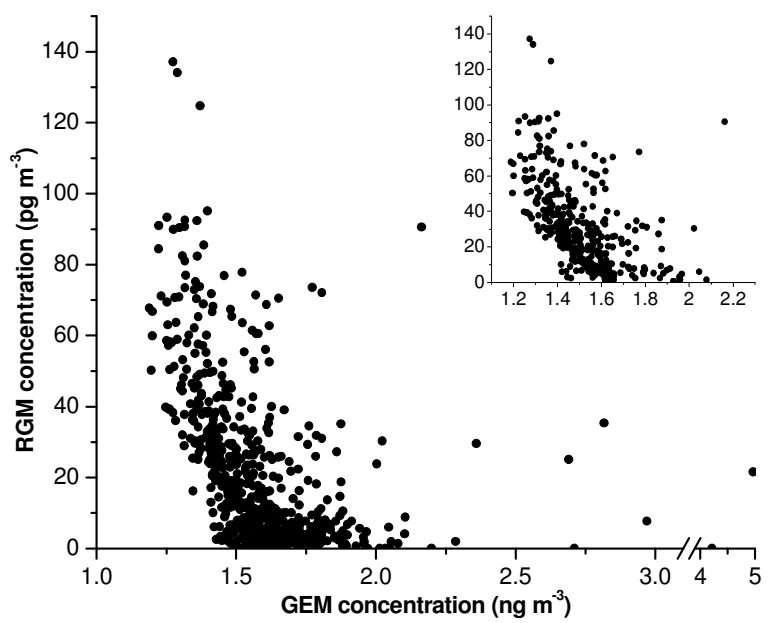

Fig. 5. Correlation between RGM and GEM concentrations for the entire study period. Insert panels show data for the 8 periods characterized as RGM enhancements only (cf. Table 1 and Fig. 1).

obtained by Selin and Jacob (2008) with the GEOS-Chem global chemical transport model. These authors suggest that strong subsidence over the East Pacific and dry conditions result in annual $\mathrm{Hg}$ (II) levels of $\sim 125-145 \mathrm{pg} \mathrm{m}^{-3}$ over the Southwest US, including our study area (Colorado). Backtrajectories (Fig. 6) indicate some presence of high tropospheric air masses (up to 400 mbar) during RGM events. RGM is correlated to water vapor mixing ratio during five high-RGM events, and is always strongly related to relative humidity (Table 1 and Fig. 7). Consequently, subsidence of free tropospheric, RGM enriched air masses may contribute to high RGM levels observed at Storm Peak Laboratory. As discussed, such high tropospheric air masses were likely the origin for high nighttime RGM levels observed at Mt. Bachelor, supported by positive relationship of RGM to ozone and inverse relationships to carbon monoxide and water vapor. 

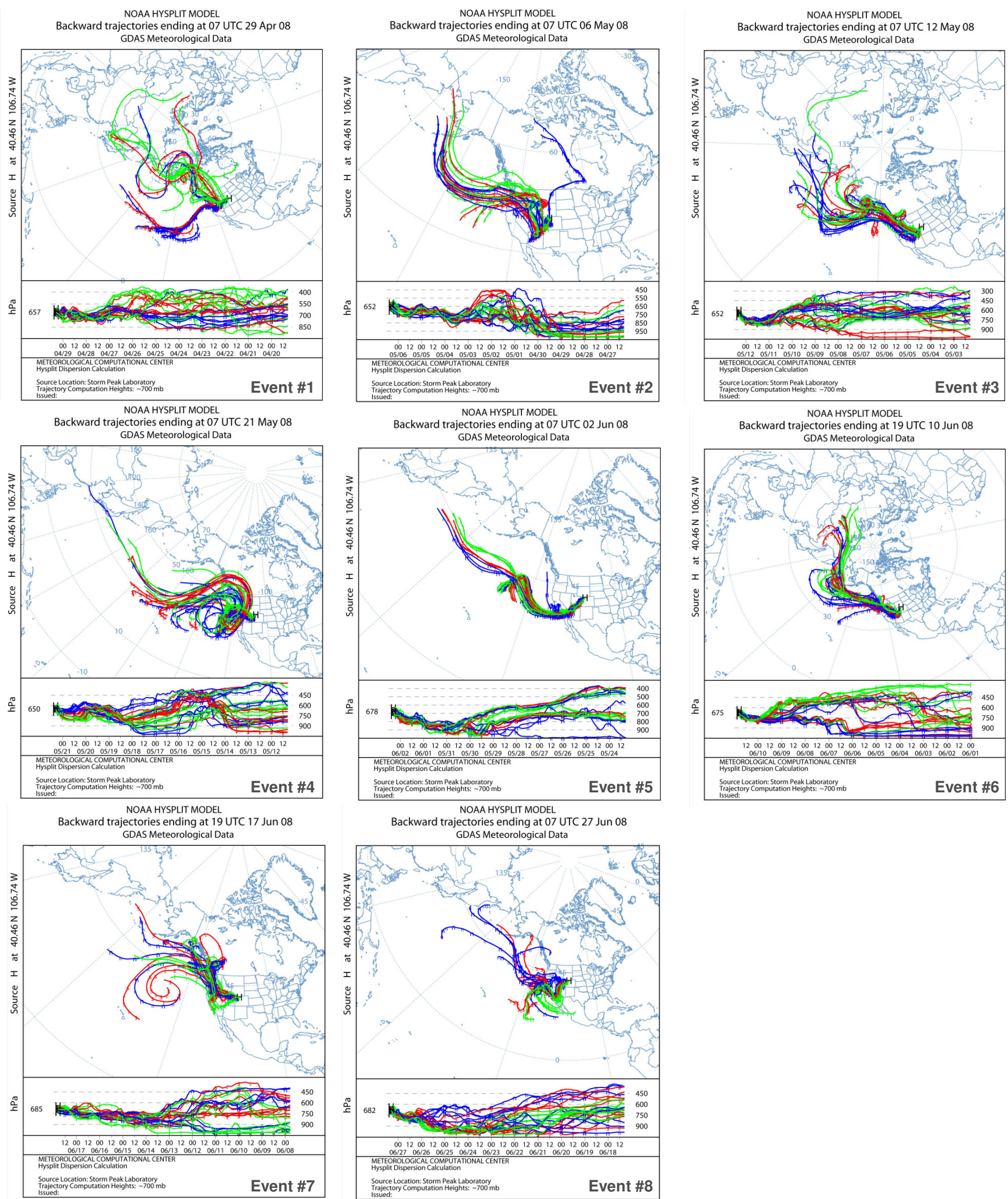

Fig. 6. 10-days HYSPLIT air mass trajectories selected for each RGM enhancement event for the time of at maximum RGM concentration. 

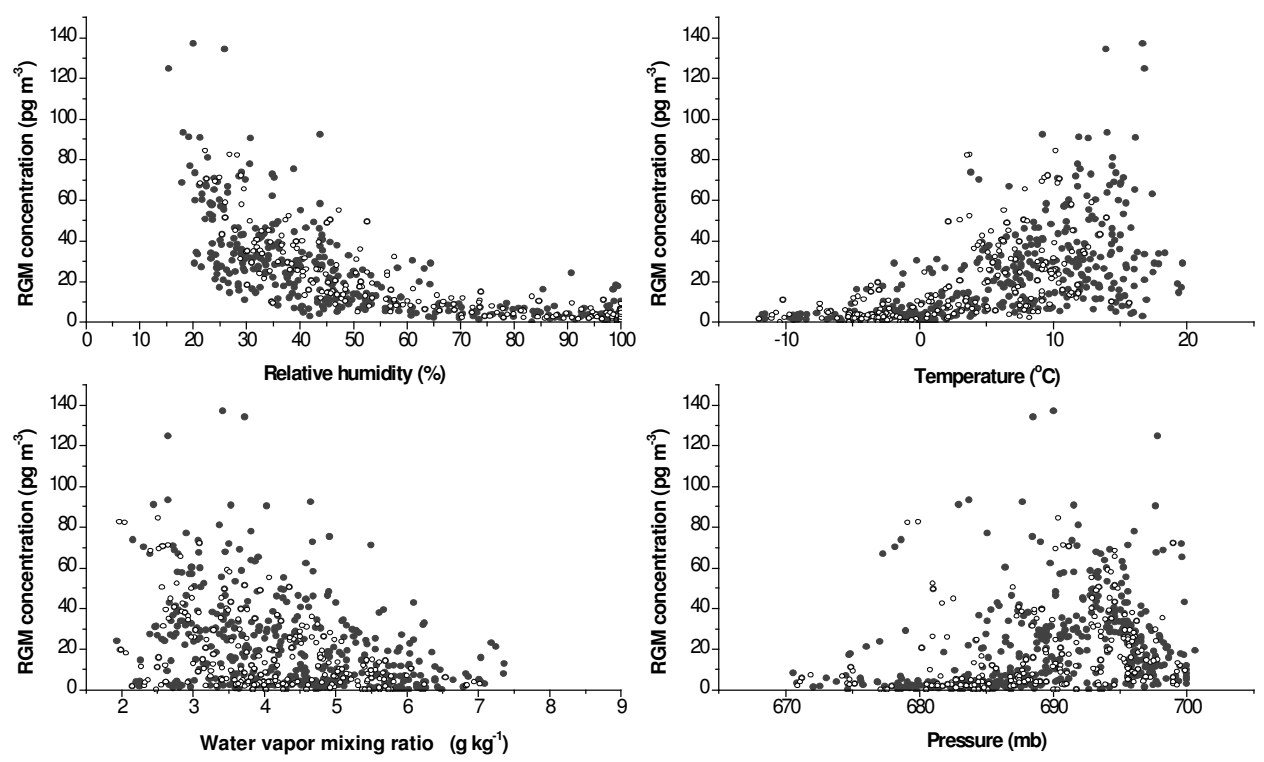

Fig. 7. RGM concentrations as a function of metrological parameters (relative humidity, temperature, water vapor mixing ratio, and pressure) for the entire study period. Opened circles report nighttime data (11:00 p.m.-6:00 a.m. local time), and closed circles show data collected during daytime (6:00 a.m.-11:00 p.m. local time).

Our data, however, does not support the notion that high RGM levels observed at Storm Peak Laboratory were exclusively related to the presence of upper tropospheric, or stratospherically influenced, air masses. The backtrajectories (Fig. 6) commonly show the presence of air masses from lower altitudes during RGM enhancements as well. In addition, RGM levels in our study were not related to high ozone levels indicative of stratospherically influence air masses. Most importantly, RGM levels remained enhanced for long time periods (up to six days) spanning multiple day/night transitions and hence different air mass representations (c.f., Fig. 4). We conclude that high RGM levels must be relatively prevalent throughout the troposphere above the Western United States, at least in late spring, and that they are not limited to upper tropospheric or stratospherically influenced air masses. Subsidence, entrainment processes, and deep vertical mixing of high tropospheric RGM may lead to the high RGM levels throughout the troposphere and even into the boundary layer under the dry, cloudless conditions over the Western United States. Deep convective mixing of free troposheric air masses have been suggested as a possible source for observed high surface RGM levels in the Nevada in the Western United States (Weiss-Penzias et al., 2009).

Based on observed air mass trajectories, another possible source origin of RGM at Storm Peak Laboratory is the North Pacific Ocean. Possibly, halogens released from sea salt aerosols might play a potential role in RGM formation, with strong surface winds in winter and spring causing high sea salt production over the North Pacific (monthly combined level of inorganic bromine species are estimated around 8 pptv in June, Yang et al., 2005). Atmospheric mer- cury speciation has not been investigated over the North Pacific ocean, but measurements during a ship cruise between Japan and Hawaii showed a distinct diurnal variation in RGM concentrations with maxima at midday, suggesting photochemically driven RGM production in the marine boundary layer (Laurier et al., 2003). Backtrajectories indicate that air masses transport duration from North Pacific to Storm Peak Laboratory is about 5 days, and tropospheric lifetime for RGM is commonly reported in the range of 1-7 days but has been estimated up to 16 days (Selin et al., 2007). Hence, it might be possible that RGM formed over the North Pacific could reach Storm Peak Laboratory, but spatially resolved RGM data (i.e., by aircraft campaigns) will be needed to confirm this hypothesis.

\subsection{Dominant control of relative humidity on RGM lev- els and scavenging processes}

The most constant variable related to high RGM levels in our study was relative humidity (RH, Fig. 7). In fact, the relationship of RGM to RH was so robust that high RGM levels were basically always present when RH dropped below $\sim 40 \%$. The relationship of RH to RGM is more pronounced than correlations to water vapor mixing ratio or to temperature, which suggest that RH directly affects RGM levels and not indirectly through either of the two RH-determining variables. Clearly, a likely reason for this relationship is that low $\mathrm{RH}$ is indicative for the presence of dry, free tropospheric air masses enriched in RGM as discussed above. However, it is striking that at low RH levels of RGM were always enhanced, completely independent of meteorological variables 
(pressure, wind speed, wind direction, time of the day) or chemical tracers (ozone, carbon monoxide, nor aerosol concentrations). This indicates a high prevalence of RGM over the Western United States when air masses are dry, notably in air with different representations of boundary layer and free tropospheric air masses. Figure 1 (bottom panel) shows that the occurrence of precipitation leads to very strong and immediate drops of RGM to levels close to the detection limit of the analyzer. It is well known that RGM has a high solubility in aqueous phase and that cloud droplets and hydrometeors serve to efficiently scavenging reactive atmospheric mercury forms (Schroeder and Munthe, 1998). This study hence emphasizes that the build-up of high RGM levels in the troposphere is likely limited to the presence of dry air masses. It seems striking, however, that the apparent control of RH on RGM levels occurs at low levels of RH, i.e., far below saturation points and presence of liquid rain droplets or ice crystals. A possible explanation for this behavior is that efficient scavenging processes for RGM may occur not only by hydrometeors, but possibly by particulates, which have been shown to be efficient surfaces for deposition of RGM such as in the polar atmosphere where RGM is readily sorbed onto aerosols present in the air (Ariya et al., 2004). Given the dominant role of RH in RGM build-up observed in this study, it might be advisable to investigate if and how humidity could control RGM scavenging processes, for example via potential effects of aerosol coating, swelling, deliquescence, or changes in aerosol size distribution and concentrations.

\section{Implications}

Measurements of atmospheric mercury speciation during spring 2008 at the high-elevation (3220 m a.s.l.) Storm Peak Laboratory showed a very regular occurrence of high RGM levels in the dry troposphere over the Rocky Mountains, Colorado. High RGM levels were not related to pollution events, but showed signs of atmospheric production, likely in the free troposphere or possibly over the Pacific Ocean. These observations provide evidence that the free tropospheric pool of mercury is enriched in divalent mercury compared to the boundary layer where high RGM levels are mainly related to local and regional pollution. The results support previous modeling studies suggesting that production of RGM could potentially be a large sink for tropospheric mercury, that high RGM levels are not limited to the upper troposphere, and that subsidence and convective mixing of tropospheric air masses can lead to high surface levels and deposition of RGM (Sillman et al., 2007; Selin and Jacob, 2008). Possible mechanism of RGM formation in the free troposphere includes gasphase production such as oxidation by halogens, but more detailed chemical characterizations are needed to confirm RGM production pathways.

High levels of RGM over these mountain areas could be of particular concern as high precipitation amounts can lead to high wet deposition rates. Specifically, snowfalls could transfer large amounts of atmospheric $\mathrm{Hg}$ (II) to snowpacks. Although photochemical reduction processes in snowpacks can cause partial re-emission of depositions (Faïn et al., 2007) the fate of mercury during snowmelt and runoff and the possible contamination of ecosystems are major issues in alpine regions. For example, fish mercury levels have been reported to exceed health consumption guidelines established by the WHO in several alpine Pyrenees lakes ( 450 to $2500 \mathrm{~m}$ a.s.1.) in France (Blais et al., 2006). In Colorado State, more than 20 lakes are marked with fish consumption advisories due to high mercury levels in fish tissue. This list includes Lake Catamount located 12 miles south of Steamboat Springs (Colorado Department of Public Health and Environment, 2009). Detailed studies are required to assess mercury deposition loads and fate processes of mercury after deposition in rain and snow in mountain areas such as the Rocky Mountains.

Acknowledgements. This research has been funded by the Colorado Department of Health, the NASA EPSCoR Research Infrastructure Development program, and the Desert Research Institute. The study has also benefited from a study funded by the National Science Foundation (ATM 0813690, Obrist D. and Luria M.). We appreciate the assistance from Steamboat Ski and Resort Corporation for continue support of Storm Peak Laboratory and our research projects. We also thank C. Berger, R. Chakrabarty, M. Kaplan, D. Lowenthal, M. Luria, S. Lyman, and H. Moosmüller for valuable discussions and inputs during this manuscript development.

Edited by: R. Ebinghaus

\section{References}

Ariya, P. A., Khalizov, A., and Gidas, A.: Reactions of gaseous mercury with atomic and molecular halogens: kinetics, product studies, and atmospheric implications, J. Phys. Chem. A, 106, 7310-7320, 2002.

Ariya, P. A., Dastoor, A. P., Amyot, M., Schroeder, W. H., Barrie, L. A., Anlauf, K., Raofie, F., Ryzhkov, A., Davignon, D., Lalonde, J. D., and Steffen, A.: The Artic, a sink for mercury, Tellus, 56B, 397-403, 2004.

Aspmo, K., Gauchard, P. A., Steffen, A., Temme, C., Berg, T., Balhmann, E., Banic, C., Dommergue, A., Ebinghaus, R., Ferrari, C., Pirrone, N., Sprovieri, F., and Wibetoe, G.: Measurements of atmospheric mercury species during an international study of mercury depletion events at Ny-Alesund, Svalbard, spring 2003. How reproducible are our present methods?, Atmos. Environ., 39, 7607-7619, doi:10.1016/j.atmosenv.2005.07.065, 2005.

Baltensperger, U., Gaggeler, H. W., Jost, D. T., Lugauer, M., Schwikowski, M., Weingartner, E., and Seibert, P.: Aerosol climatology at the high-alpine site Jungfraujoch, Switzerland, J. Geophys. Res., 102, 19707-19715, 1997.

Bergan, T. and Rodhe, H.: Oxidation of elemental mercury in the atmosphere; constraints imposed by global scale modelling, J. Atmos. Chem., 40, 191-212, 2001. 
Blais, J. M., Charpentie, S., Pick, F., Kimpe, L. E., Amand, A. S., and Regnault-Roger, C.: Mercury, polybrominated diphenyl ether, organochlorine pesticide, and polychlorinated biphenyl concentrations in fish from lakes along an elevation transect in the French Pyrenees, Ecotoxicol. Environ. Saf., 63, 91-99, doi:10.1016/j.ecoenv.2005.08.008, 2006.

Borys, R. D. and Wetzel, M. A.: Storm peak laboratory: A research, teaching, and service facility for the atmospheric sciences, Bull. Amer. Meteor. Soc., 78, 2115-2123, 1997.

Caldwell, C. A., Swartzendruber, P., and Prestbo, E.: Concentration and dry deposition of mercury species in arid south central New Mexico (2001-2002), Environ. Sci. Technol., 40, 75357540, doi:10.1021/es0609957, 2006.

Calvert, J. G. and Lindberg, S. E.: A modeling study of the mechanism of the halogen-ozone-mercury homogeneous reactions in the troposphere during the polar spring, Atmos. Environ., 37, 4467-4481, doi:10.1016/j.atmosenv.2003.07.001, 2003.

Calvert, J. G. and Lindberg, S.: Mechanisms of mercury removal by $\mathrm{O}_{3}$ and $\mathrm{OH}$ in the atmosphere, Atmos. Environ., 39, 3355-3367, doi:10.1016/j.atmosenv.2005.01.055, 2005.

Cobbett, F. D., Steffen, A., Lawson, G., and Van Heyst, B. J.: GEM fluxes and atmospheric mercury concentrations (GEM, RGM and Hg-P) in the Canadian Arctic at Alert, Nunavut, Canada (February-June 2005), Atmos. Environ., 41, 6527-6543, doi:10.1016/j.atmonsenv.2007.04.033, 2007.

Colorado Department of Public Health and Environment: Colorado Fish Tissue Study, data online available from http://www.cdphe. state.co.us/wq/fishcon/index.html, 2009.

Dastoor, A. P. and Larocque, Y.: Global circulation of atmospheric mercury: a modelling study, Atmos. Environ., 38, 147-161, doi:10.1016/j.atmosenv.2003.08.037, 2004.

Donohoue, D. L., Bauer, D., and Hynes, A. J.: Temperature and pressure dependent rate coefficients for the reaction of $\mathrm{Hg}$ with $\mathrm{Cl}$ and the reaction of $\mathrm{Cl}$ with $\mathrm{Cl}$ : a pulsed laser photolysispulsed laser induced fluorescence study, J. Phys. Chem., 109, 7732-7741, doi:10.1021/jp0513541, 2005.

Donohoue, D. L., Bauer, D., Cossairt, B., and Hynes, A. J.: Temperature and Pressure Dependent Rate Coefficients for the Reaction of $\mathrm{Hg}$ with $\mathrm{Br}$ and the Reaction of $\mathrm{Br}$ with $\mathrm{Br}$ : A Pulsed Laser Photolysis-Pulsed Laser Induced luorescence Study, J. Phys. Chem., 110, 6623-6632, doi:10.1021/jp054688j, 2006.

Draxler, R. R., and Rolph, G. D.: HYSPLIT (HYbrid SingleParticle Lagrangian Integrated Trajectory) Model Access via NOAA ARL READY Website. NOAA Air Resources Laboratory, Silver Spring, MD. Available from: http://www.arl.noaa. gov/ready/hysplit4.html, 2003.

Ebinghaus, R., Jennings, S. G., Schroeder, W. H., Berg, T., Donaghy, T., Guentzel, J., Kenny, C., Kock, H. H., Kvietkus, K., Landing, W., Muhleck, T., Munthe, J., Prestbo, E. M., Schneeberger, D., Slemr, F., Sommar, J., Urba, A., Wallschlager, D., and Xiao, Z.: International field intercomparison measurements of atmospheric mercury species at Mace Head, Ireland, Atmos. Environ., 33, 3063-3073, 1999.

Faïn, X., Grangeon, S., Balhmann, E., Fritsche, J., Obrist, D., Dommergue, A., Ferrari, C., Cairns, W., Ebinghaus, R., Barbante, C., Cescon, P., and Boutron, C.: Diurnal production of gaseous mercury in the alpine snowpack before snowmelt, J. Geophys. Res., 112, D21311, doi:10.1029/2007JD008520, 2007.

Friedli, H. R., Radke, L. F., Prescott, R., Li, P., Woo, J. H., and
Carmichael, G. R.: Mercury in the atmosphere around Japan, Korea, and China as observed during the 2001 ACE-Asia field campaign: Measurements, distributions, sources, and implications, J. Geophys. Res., 109, D19S25, doi:10.1029/2003jd004244, 2004.

Gabriel, M. C., Williamson, D. G., Brooks, S., and Lindberg, S.: Atmospheric speciation of Southeastern mercury in two contrasting US airsheds, Atmos. Environ., 39, 4947-4958, doi:10.1016/j.atmosenv.2005.05.003, 2005.

Goodsite, M. E., and Plane, J. M. C.: A Theoretical Study of the Oxidation of $\mathrm{Hg}$ to $\mathrm{HgBr}_{2}$ in the Troposphere, Environ. Sci. Technol., 38, 1772-1776, doi:10.1021/es034680s, 2004.

Hall, B. D., Olson, M. L., Rutter, A. P., Frontiera, R. R., Krabbenhoft, D. P., Gross, D. S., Yuen, M., Rudolph, T. M., and Schauer, J. J.: Atmospheric mercury speciation in Yellowstone National Park, Sci. Total Environ., 367, 354-366, doi:10.1016/j.scitotenv.2005.12.007, 2006.

Hallar, A. G., Obrist, D., McCubbin, I., Fain, X., and Rahn, T.: Chemical and Aerosol Signatures of Biomass Burning via Long Range Transport observed at Storm Peak Laboratory, AGU fall meeting, Abstract A21B-0137, 2008.

Hedgecock, I. M., Trunfio, G. A., Pirrone, N., and Sprovieri, F.: Mercury chemistry in the MBL: Mediterranean case and sensitivity studies using the AMCOTS (Atmospheric Mercury Chemistry over the Sea) model, Atmos. Environ., 39, 7217-7230, doi:10.1016/j.atmosenv.2005.09.002, 2005.

Hindman, E. E., Campbell, M. A., and Borys, R. D.: A 10-winter record of cloud-droplet physical and chemical-properties at a mountaintop site in Colorado, J. Appl. Meteorol., 33, 797-807, 1994.

Landis, M. S., Stevens, R. K., Schaedlich, F., and Prestbo, E. M.: Development and Characterization of an Annular Denuder Methodology for the Measurement of Divalent Inorganic Reactive Gaseous Mercury in Ambient Air, Environ. Sci. Technol., 36, 3000-3009, 2002.

Laurier, F., Mason, R. P., Whalin, L., and Kato, S.: Reactive gaseous mercury formation in the North Pacific Ocean's marine boundary layer: A potential role of halogen chemistry, J. Geophys. Res., 108, 4529, doi:10.1029/2003JD003625, 2003.

Lindberg, S. E., and Stratton, W. J.: Atmospheric mercury speciation: concentrations and behaviour of reactive gaseous mercury in ambient air, Environ. Sci. Technol., 32, 49-57, 1998.

Lindberg, S. E., Brooks, S., Lin, C.-J., Scott, K. J., Landis, M. S., Stevens, R. K., Goodsite, M., and Richter, A.: Dynamic Oxidation of Gaseous Mercury in the Arctic Troposphere at Polar Sunrise, Environ. Sci. Technol., 36, 1245-1256, 2002.

Lowenthal, D. H., Borys, R. D., and Wetzel, M. A.: Aerosol distributions and cloud interactions at a mountaintop laboratory, J. Geophys. Res., 107, 4345, doi:10.1029/2001jd002046, 2002.

Lowenthal, D. H., Borys, R. D., Choularton, T. W., Bower, K. N., Flynn, M. J., and Gallagher, M. W.: Parameterization of the cloud droplet-sulfate relationship, Atmos. Environ., 38, 287292, doi:10.1016/j.atmosenv.2003.09.046, 2004.

Lyman, S. N. and Gustin, M. S.: Speciation of atmospheric mercury at two sites in northern Nevada, USA, Atmos. Environ., 42, 927939, doi:10.1016/j.atmosenv.2007.10.012, 2008.

Murphy, D. M., Hudson, P. K., Thomson, D. S., Sheridan, P. J., and Wilson, J. C.: Observations of mercury-containing aerosols, Environ. Sci. Technol., 40, 3163-3167, doi:10.1021/es052385x, 2006. 
Obrist, D., Hallar, A. G., McCubbin, I., Stephens, B. B., and Rahn, T.: Atmospheric mercury concentrations at Storm Peak Laboratory in the Rocky Mountains: Evidence for long-range transport from Asia, boundary layer contributions, and plant mercury uptake, Atmos. Environ., 42, 7579-7589, doi:10.1016/j.atmosenv.2008.06.051, 2008.

Pal, B. and Ariya, P. A.: Gas-phase HO center dot-Initiated reactions of elemental mercury: kinetics, product studies, and atmospheric implications, Environ. Sci. Technol., 38, 5555-5566, doi:10.1021/es0494353, 2004.

Poissant, L., Pilote, M., Beauvais, C., Constant, P., and Zhang, H. H.: A year of continuous measurements of three atmospheric mercury species (GEM, RGM and $\mathrm{Hg}-\mathrm{p}$ ) in southern Quebec, Canada, Atmos. Environ., 39, 1275-1287, doi:10.1016/j.atmosenv.2004.11.007, 2005.

Radke, L. F., Friedli, H. R., and Heikes, B. G.: Atmospheric mercury over the NE Pacific during spring 2002: Gradients, residence time, upper troposphere lower stratosphere loss, and long-range transport, J. Geophys. Res., 112, D19305, doi:10.1029/2005jd005828, 2007.

Raofie, F. and Ariya, P. A.: Product study of the gas-phase BrOinitiated oxidation of $\mathrm{Hg}^{0}$ : evidence for stable $\mathrm{Hg}^{1+}$ compounds, Environ. Sci. Technol., 38, 4319-4326, doi:10.1021/es035339a, 2004.

Rolph, G. D.: Real-time Environmental Applications and Display system (READY) Website. NOAA Air Resources Laboratory, Silver Spring, MD, USA, online available at: http://www.arl. noaa.gov/ready/hysplit4.html, 2003.

Schroeder, W. H., Keeler, G., Kock, H., Roussel, P., Schneeberger, D., and Schaedlich, F.: International field intercomparison of atmospheric mercury measurement methods, Water Air Soil Pollut., 80, 611-620, 1995.

Schroeder, W. H. and Munthe, J.: Atmospheric mercury - An overview, Atmos. Environ., 32, 809-822, 1998.

Seibert, P., Kromp-Kolb, H., Kasper, A., Kalina, M., Puxbaum, H., Jost, D. T., Schwikowski, M., and Baltensperger, U.: Transport of polluted boundary layer air from the Po Valley to high-alpine sites, Atmos. Environ., 32, 3953-3965, 1998.

Seigneur, C., Vijayaraghavan, K., and Lohman, K.: Atmospheric mercury chemistry: Sensitivity of global model simulations to chemical reactions, J. Geophys. Res., 111, D22306, doi:10.1029/2005jd006780, 2006.

Selin, N. E., Jacob, D. J., Park, R. J., Yantosca, R. M., Strode, S. A., Jaegle, L., and Jaffe, D.: Chemical cycling and deposition of atmospheric mercury: Global constraints from observations, J. Geophys. Res., 112, D02308, doi:10.1029/2006JD007450, 2007.

Selin, N. E. and Jacob, D. J.: Seasonal and spatial patterns of mercury wet deposition in the United States: Constraints on the contribution from North American anthropogenic sources, Atmos. Environ., 42, 5193-5204, doi:10.1016/j.atmosenv.2008.02.069, 2008.

Shepler, B. C. and Peterson, K. A.: Mercury monoxide: A systematic investigation of its ground electronic state, J. Phys. Chem., 107, 1783-1787, doi:10.1021/jp027512f, 2003.

Sheu, G.-R., Lin, N.-H., Wang, J.-L., Lee, C.-T., and Chang, S.S.: Characterization of speciated atmospheric mercury measured at a high-elevation background station in East Asia: Transport and transformation, 9th International Conference on Mercury as a Global Pollutant, Abstract S06-05, 2009.
Sillman, S., Marsik, F. J., Al-Wali, K. I., Keeler, G. J., and Landis, M. S.: Reactive mercury in the troposphere: Model formation and results for Florida, the northeastern United States, and the Atlantic Ocean, J. Geophys. Res., 112, D23305, doi:10.1029/2006jd008227, 2007.

Slemr, F., Ebinghaus, R., Brenninkmeijer, C. A. M., Hermann, M., Kock, H. H., Martinsson, B. G., Schuck, T., Sprung, D., van Velthoven, P., Zahn, A., and Ziereis, H.: Gaseous mercury distribution in the upper troposphere and lower stratosphere observed onboard the CARIBIC passenger aircraft, Atmos. Chem. Phys., 9, 1957-1969, 2009, http://www.atmos-chem-phys.net/9/1957/2009/.

Sommar, J., Gardfeldt, K., Strömberg, D., and Feng, X.: A kinetic study of the gas-phase reaction between the hydroxyl radical and atomic mercury, Atmos. Environ., 35, 3049-3054, 2001.

Swartzendruber, P. C., Jaffe, D. A., Prestbo, E. M., Weiss-Penzias, P., Selin, N. E., Park, R., Jacob, D. J., Strode, S., and Jaegle, L.: Observations of reactive gaseous mercury in the free troposphere at the Mount Bachelor Observatory, J. Geophys. Res., 111, D24302, doi:10.1029/2006jd007415, 2006.

Swartzendruber, P. C., Chand, D., Jaffe, D. A., Smith, J., Reidmiller, D., Gratz, L., Keeler, J., Strode, S., Jaegle, L., and Talbot, R.: Vertical distribution of mercury, CO, ozone, and aerosol scattering coefficient in the Pacific Northwest during the spring 2006 INTEX-B campaign, J. Geophys. Res.-Atmos., 113, doi:10.1029/2007jd009579, 2008.

Talbot, R., Mao, H., Scheuer, E., Dibb, J., and Avery, M.: Total depletion of $\mathrm{Hg}$ degrees in the upper troposphere-lower stratosphere, Geophys. Res. Lett., 34, L23804, doi:10.1029/2007GL031366, 2007.

Tossel, J. A.: Calculation of the Energetics for Oxidation of GasPhase Elemental $\mathrm{Hg}$ by Br and BrO, J. Phys. Chem., 107, 78047808, 2003.

Valente, R. J., Shea, C., Humes, K. L., and Tanner, R. L.: Atmospheric mercury in the Great Smoky Mountains compared to regional and global levels, Atmos. Environ., 41, 1861-1873, doi:10.1016/j.atmosenv.2006.10.054, 2007.

Weiss-Penzias, P., Jaffe, D. A., Swartzendruber, P., Dennison, J. B., Chand, D., Hafner, W., and Prestbo, E.: Observations of Asian air pollution in the free troposphere at Mount Bachelor Observatory during the spring of 2004, J. Geophys. Res., 111, D10304, doi:10.1029/2005jd006522, 2006.

Weiss-Penzias, P., Gustin, M. S., and Lyman, S. N.: Observations of speciated atmospheric mercury at three sites in Nevada: Evidence for a free tropospheric source of reactive gaseous mercury, J. Geophys. Res.-Atmos., 114, doi:10.1029/2008jd011607, 2009.

Yang, X., Cox, R. A., Warwick, N. J., Pyle, J. A., Carver, G. D., O'Connor, F. M., and Savage, N. H.: Tropospheric bromine chemistry and its impacts on ozone: A model study, J. Geophys. Res., 110, D23311, doi:10.1029/2005jd006244, 2005.

Yatavelli, R. L. N., Fahrni, J. K., Kim, M., Crist, K. C., Vickers, C. D., Winter, S. E., and Connell, D. P.: Mercury, $\mathrm{PM}_{2.5}$ and gaseous co-pollutants in the Ohio River Valley region: Preliminary results from the Athens supersite, Atmos. Environ., 40, 6650-6665, doi:10.1016/j.atmosenv.2006.05.072, 2006. 